nobody has yet produced guidelines which might deprive people of drugs they need on grounds of cost.

RICHARD A BEST Consultant Cardiologist, Burnley General Hsopital

\section{Response from the Editor}

We are delighted to know that Dr Smith is reading Clinical Medicine. He found us wanting. We have already addressed the conflict of interest issue, having now included an appropriate question in the instructions to authors (see back cover of the journal).

PETER WATKINS

Editor, Clinical Medicine

\section{Respiratory failure: two forgotten concepts}

Editor - Writing in the CME section of Clinical Medicine, Dr Vincent Mak (Clin Med JRCPL July/August 2001, pp290-1) quotes the oxygen combining power of haemaglobin as $1.34 \mathrm{ml} / \mathrm{g}$. This figure is frequently quoted but is probably incorrect. Nunn ${ }^{1}$ explains as follows:

"Until 1963 the value (oxygen combining power of haemoglobin) was taken to be $1.34 \mathrm{ml} / \mathrm{g}$. Following the precise determination of the molecular weight of haemo- globin, the theoretical value of $1.39 \mathrm{ml} / \mathrm{g}$ was derived and passed into general use. However, it gradually became clear that this value was not obtained when direct measurements of haemoglobin concentration and oxygen capacity were compared. After an exhaustive study of the subject, Gregory ${ }^{2}$ proposed the value of $1.306 \mathrm{ml} / \mathrm{g}$ for human adult blood."

\section{References}

1 Nunn JF. Applied respiratory physiology (3rd edition). Cambridge: Butterworth, 1989.

2 Gregory IC. The oxygen and carbon dioxide capacities of foetal and adult blood. Journal of Physiology 1974;236: 625.

MARK HARRIES British Olympic Medical Team

\section{Fever of unknown origin}

Editor - I read with interest the article on fever of unknown origin (Clin Med JRCPL May/June 2001, pp177-9). In their introduction the authors state that this descriptive term was first used in 1961. While this may be true of 'FUO', the diagnosis of 'pyrexia of unknown origin' is of much earlier vintage. During the First World War, many cases of fever of obscure origin were reported among the troops serving in France and this gave rise to much concern in the army medical services. The illness was said to be rarely fatal but to give rise to much disability among the fighting men. A committee formed to study the problem published its findings in the British Medical Journal (BMJ 19th Jan, 1918: pp91-5), describing the clinical features of 'PUO' (also referred to as trench fever) and pointing out that this was much more common than that ancient scourge of war - enteric or typhoid fever. On the whole the prognosis seems to have been good, with half the men returning to active duty while the rest were evacuated and further follow up is not stated. I hope that this minor historical footnote may be of interest to readers of the journal.

RAYMOND RAULT Pittsburgh, USA 